\title{
PENGEMBANGAN MODEL PENGELOLAAN RISIKO SISTEM INFORMASI BERBASIS FMEA DAN ISO 31000:2009 SEBAGAI PENDUKUNG K3L DI LABORATORIUM LINGKUNGAN
}

\author{
AGIE ADHITYA ${ }^{1}{ }^{1}$, CHRISTINE SURYADI ${ }^{2}$ \\ 1. Sekolah Tinggi Analis Bakti Asih, Bandung, Indonesia \\ 2. Sekolah Teknik Elektro dan Informatika, Institut Teknologi Bandung \\ Bandung, Indonesia \\ Email : adhitya.agie@gmail.com
}

\begin{abstract}
ABSTRAK
Laboratory Information Management Systems (LIMS) merupakan SI berbasis komputer yang bermanfaat bagi laboratorium dalam meningkatkan keamanan, produktifitas dan akurasi data, mengelola semua informasi yang berkaitan dengan kegiatan laboratorium serta memungkinkan laboratorium untuk menampilkan data serta laporan secara cepat. Penelitian dilakukan dengan cara merancang model pengelolaan risiko SI untuk menilai risiko-risiko yang berkaitan dengan pemanfaatan SI di Laboratorium Uji Kimia X dengan memanfaatkan kerangka kerja FMEA dan acuan ISO 31000. Penerapan model pada Laboratorium Uji Kimia X berhasil mengidentifikasi enam belas risiko SI. Sementara hasil penilaian dan analisis risiko-risiko SI tersebut menyatakan bahwa terdapat dua risiko yang termasuk kedalam kategori kritis dengan nilai Risk Priority Number (RPN) secara berurutan yaitu 75 dan 100. Sistem ini dapat diterapkan untuk mendeteksi bahaya dan risiko di laboratorium lingkungan.
\end{abstract}

Kata kunci: FMEA, ISO 31000, LIMS, risiko SI, environmental laboratory

\begin{abstract}
Laboratory Information Management Systems (LIMS) is a computerized IS used by laboratory to increase safety, data productivity and accuracy, manage information related to laboratory activities and allow laboratory to display data and reports faster. The research was conducted by creating IS risk management model using FMEA framework and ISO 31000 standard to assess risks related to IS implementation in Chemical Testing Laboratory $X$. The result of model testing in case study Chemical Testing Laboratory $X$ manage to identify 16 IS risks threatening IS assets. Analysis of these risk produce two risks that fall in critical category. UTP cable damage and data input errors. Risk Priority Number (RPN) value for each risks are 100, and 75, respectively. This system can be implemented to detect the risk of hazards that may occur in the environmental laboratory.
\end{abstract}

Keywords: FMEA, ISO 31000, LIMS, IS risks, IS assets, environmental laboratory. 


\section{PENDAhUluan}

Aktivitas di laboratorium lingkungan sangat berpotensi dalam menimbulkan terjadinya suatu kecelakaan dikarenakan adanya penggunaan alat dan bahan-bahan kimia dan/atau mikroorganisme patogen serta fasilitas pendukung lainnya seperti air, gas, listrik dan almari asam (Amanah, 2011). Oleh karena itu upaya meminimalkan risiko bahaya di laboratorium, sistem Kesehatan Keselamatan Kerja dan Lingkungan (K3L) diterapkan dengan pendekatan manajemen risiko yang memiliki 3 tahapan yaitu identifikasi bahaya, penilaian risiko dan pengendalian risiko (Permana dkk, 2013). Pengembangan manajemen risiko saat ini mulai berkolaborasi dengan bidang sistem informasi (SI) untuk mempermudah pihak manajemen dalam melakukan prioritasi risiko, sehingga dalam pengendalian risiko menjadi lebih efisien baik dari segi waktu maupun anggaran.

Sistem Informasi (SI) merupakan bagian tak terpisahkan dari aktivitas bisnis sehari-hari bahkan dapat dikatakan bahwa proses bisnis dan strategi pembuatan keputusan dari suatu perusahaan saat ini memiliki ketergantungan yang sangat tinggi terhadap SI (Laudon \& Laudon, 1998; O'Brien \& Marakas, 2011). Salah satu bisnis yang memiliki ketergantungan terhadap SI adalah laboratorium pengujian. Seiring perkembangannya, laboratorium menghadapi masalah ketika diharuskan untuk menampilkan informasi secara cepat namun akurat dikarenakan data yang harus diolah jumlahnya sangat banyak (Paszko \& Pugsley, 2000). Solusi dari hal tersebut adalah penggunaan LIMS (Tagger, 2011). Berdasarkan hasil survey yang dilakukan oleh Pharma-IQ, diketahui bahwa LIMS merupakan teknologi yang paling banyak digunakan oleh laboratorium di seluruh dunia (Madigan, 2011). Menurut Madigan, dengan memanfaatkan LIMS, laboratorium mampu menampilkan 200-300 laporan pengujian setiap harinya. Namun upaya penerapan LIMS bukanlah tanpa masalah. Sebuah artikel yang diterbitkan oleh AACC (American Association for Clinical Chemistry) mempublikasikan beberapa kejadian kegagalan LIMS, salah satunya adalah kegagalan mendeteksi bug pada perangkat lunak yang digunakan untuk menghitung risiko Down's Syndrome. Kegagalan tersebut berlangsung selama lima bulan lamanya yang berakibat pada tidak terdeteksinya 158 kehamilan berisiko tinggi (Yu, 2012). Dalam literatur lain, ditekankan pentingnya upaya untuk mengevaluasi dan mengantisipasi risiko-risiko yang berkaitan dengan penerapan SI sebagai upaya meminimalkan kegagalan dan kerusakan baik secara fisik maupun logis terhadap sumber-sumber daya SI (Jakaria, dkk, 2013; Novak-deLaurell, 2014; Wiesche, dkk, 2013; Yucel, dkk, 2011). Menurut Yaumi dan Surendro, pengelolaan risiko merupakan proses fundamental dan kompleks sebagai bagian dari SI untuk menilai, mengevaluasi, dan memitigasi risiko SI secara berkelanjutan (Yaumi \& Surendro, 2012).

Pada studi ini pengembangan metode pengelolaan risiko dilakukan di laboratorium Uji Kimia $X$ yang merupakan salah satu laboratorium pengujian kualitas lingkungan yang mencakup air, tanah, udara, pangan dan logam yang telah menerapkan SNI ISO/IEC 17025 sebagai acuan dalam kegiatan pengelolaan laboratoriumnya serta LIMS dalam membantu kegiatan sehari-harinya. Penerapan LIMS di Laboratorium Uji Kimia X telah dilakukan sejak 2010. Bekerja dalam laboratorium kimia, ataupun industri kimia dan pertambangan memiliki risiko terhadap keselamatan kerja dikarenakan banyak kegiatan laboratorium kimia menggunakan bahan-bahan kimia yang berbahaya (Permana dkk, 2013). Hasil identifikasi dan inventori, sebuah laboratorium kimia organik sebagian besar terkategori bahan berbahaya dan beracun (B3) sehingga berpotensi menimbulkan risiko berbahaya bagi pekerja dan lingkungan (Subamia dkk, 2019). Menurut Fatimah dan Septiawati (2018) pekerja laboratorium industri minyak dapat terkena paparan benzene selama proses proses pengolahan sampel minyak, dimana dari 31 pekerja laboratorium 12 pekerja diantaranya dinyatakan terkena paparan benzene selama bekerja di laboatorium sehingga berisiko menimbulkan efek karsinogenik. 
Hal ini disebabkan karena benzene masuk kedalam tubuh dalam bentuk uap melalui proses inhalasi dan absorbsi di paru-paru, dan jika tubuh terpapar benzene selama 8 jam per hari maka risiko keracunan benzene semakin tinggi sehingga pada akhirnya akan berpengaruh terhadap susunan saraf (Kartikasari dkk, 2016).

Mengingat pentingnya keselamatan dan kesehatan pekerja di laboratorium lingkungan maka penelitian ini mengangkat masalah yang timbul pada pemanfaatan SI pada laboratorium pengujian kimia, khususnya LIMS pada Laboratorium Uji Kimia X. masalah-masalah tersebut antara lain : (a) Bagaimana merancang model pengelolaan risiko SI dengan memanfaatkan kerangka kerja ISO 31000 dan FMEA; (b) Bagaimana melakukan identifikasi terhadap risikorisiko SI yang mungkin terjadi di laboratorium pengujian; (c) Bagaimana melakukan penilaian terhadap risiko-risiko SI yang teridentifikasi di laboratorium pengujian; (d) Bagaimana menentukan tindakan penanganan risiko yang tepat terhadap risiko-risiko SI yang teridentifikasi di laboratorium pengujian.

Penelitian ini ditujukan untuk merancang sebuah model pengelolaan risiko SI dengan memanfaatkan kerangka kerja FMEA dan acuan ISO 31000, melakukan identifikasi dan penilaian risiko SI laboratorium lingkungan dengan memanfaatkan model yang telah dirancang, serta menentukan usulan tindakan penanganan risiko yang tepat terhadap risikorisiko SI yang teridentifikasi pada studi kasus Laboratorium Uji Kimia X.

\section{BAHAN DAN METODE}

Metodologi yang digunakan dalam penelitian ini memanfaatkan Design Science Research Methodology (DSRM) yang diusulkan oleh Peffers dimana terdapat 6 (enam) tahapan penelitian seperti terlihat pada Gambar 1 berikut ini (Peffers, 2007).

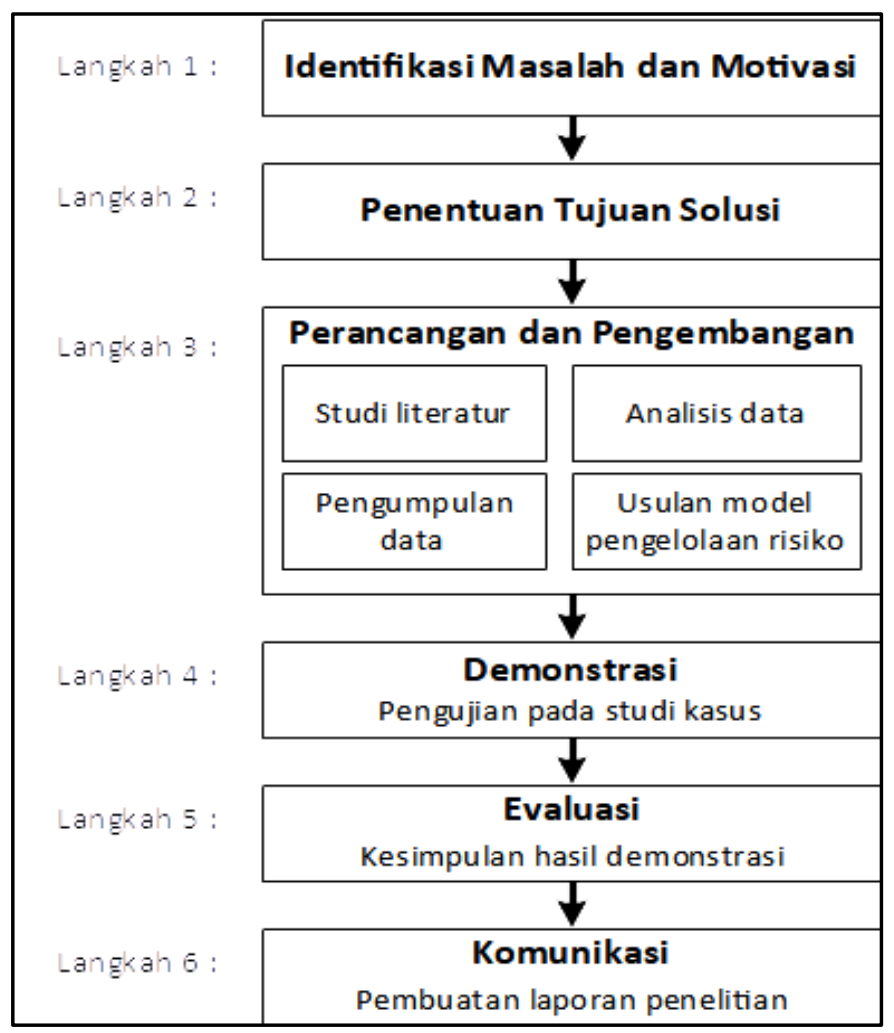

Gambar 1. Langkah penelitian 
Langkah identifikasi masalah dan motivasi serta penentuan tujuan telah dijabarkan pada bagian pendahuluan makalah ini. Langkah selanjutnya adalah merancang dan mengembangkan model yang digunakan pada penelitian ini. Model pengelolaan risiko SI dirancang dengan memperhatikan konteks organisasi yang didapat melalui proses diskusi dan wawancara. Kemudian ditetapkan pula kriteria risiko yang mencerminkan nilai-nilai yang dianut oleh organisasi, serta tujuan dan sumber daya yang dimiliki oleh organisasi.

Proses pengelolaan risiko menurut acuan ISO 31000 terdiri dari tujuh tahap yaitu komunikasi, penentuan konteks, identifikasi risiko, analisis risiko, evaluasi risiko, penanganan risiko, dan pengawasan. Pada tabel 1 dapat terlihat pemetaan kerangka kerja FMEA terhadap tahapan pengelolaan risiko berdasarkan acuan ISO 31000.

Tabel 1. Pemetaan FMEA terhadap ISO 31000

\begin{tabular}{ll}
\hline \multicolumn{1}{c}{ ISO 31000 } & \multicolumn{1}{c}{ FMEA } \\
\hline Komunikasi & Diskusi dan brainstorming \\
\hline Penentuan Konteks & Tidak ada \\
\hline Identifikasi risiko & Identifikasi risiko \\
\hline Analisis risiko & Penentuan nilai severity (S), occurrence (O) dan detection (D) \\
& Penentuan nilai Risk Score (RS) dan Risk Priority Number (RPN) \\
\hline Evaluasi risiko & Pembuatan Diagram Pareto nilai RS dan RPN \\
& Penentuan ambang batas nilai RS dan RPN \\
& Membuat Diagram Acak antara nilai RS dan RPN \\
& Menentukan titik temu antara ambang batas RS dan RPN \\
\hline Penanganan risiko & Menentukan respon terhadap risiko kritis \\
\hline Pengawasan & Evaluasi ulang nilai S, O dan D \\
& Evaluasi ulang nilai RS dan RPN \\
\hline
\end{tabular}

Identifikasi risiko merupakan proses menemukan, mengenali dan mencatat risiko. Tujuan dilakukannya proses identifikasi risiko adalah untuk mengetahui kejadian atau skenario kejadian yang dapat mempengaruhi tercapainya sasaran sistem atau tujuan organisasi. Analisis risiko merupakan proses pengembangan atas pemahaman terhadap risiko. Dalam proses ini dilakukan penentuan tingkat dampak dan kemungkinan kejadian dari masingmasing risiko yang teridentifikasi serta mempertimbangkan ada atau tidaknya serta efektifitas pengawasan yang dilakukan. Tujuan evaluasi risiko adalah menjadikan hasil analisis risiko sebagai dasar pembuatan keputusan berkaitan dengan penanganan risiko dengan mempertimbangkan kriteria risiko yang telah ditetapkan sebelumnya. Penanganan risiko merupakan proses pemilihan opsi untuk memodifikasi risiko dan menerapkan opsi tersebut dengan cara menerapkan atau memodifikasi pengawasan/pengendalian risiko (ISO, 2009).

\section{HASIL DAN PEMBAHASAN}

Model pengelolaan risiko SI pada penelitian ini dirancang dengan memanfaatkan kerangka kerja FMEA dan acuan ISO 31000:2009. ISO 31000:2009 digunakan sebagai acuan pelaksanaan pengelolaan risiko secara keseluruhan, sementara FMEA digunakan untuk melakukan penilaian terhadap risiko SI yang teridentifikasi. Model ini dirancang dan dikembangkan dengan tujuan untuk mengidentifikasi, dan menilai risiko-risiko yang mungkin timbul pada penerapan sebuah SI, khususnya LIMS. Tahapan dalam rancangan model ini dimulai dengan mengidentifikasi sumber daya SI yang ada pada proses bisnis utama laboratorium pengujian kimia, yaitu proses pengujian contoh uji. Tahap selanjutnya adalah mengidentifikasi jenis kegagalan/kesalahan yang mungkin terjadi pada masing-masing 
sumber daya SI kemudian dilanjutkan dengan mengidentifikasi dampak dari masing-masing kegagalan tersebut. Hasil dari kegiatan identifikasi risiko SI ini adalah berupa daftar risiko SI yang akan digunakan pada tahapan analisis risiko SI. Dari daftar risiko yang dihasilkan pada tahap identifikasi risiko SI, selanjutnya dilakukan analisis untuk menentukan tingkat dampak dari masing-masing risiko (severity) dan penentuan tingkat kemungkinan kejadian risiko (occurrence). Kemudian dilanjutkan dengan menghitung nilai dari masing-masing risiko (Risk Score). Risk Score (RS) merupakan hasil dari perkalian severity (S) dan occurrence (O). Selanjutnya dilakukan penentuan tingkat efektifitas control yang ada (detection). Risk Priority Number (RPN) didapat dengan melakukan perkalian antara RS dan detection (D) (Carbone \& Tippett, 2004). Dari hasil analisis risiko SI, dilakukan evaluasi risiko SI dengan cara membuat diagram Pareto terhadap nilai RS dan RPN sebagai bahan penentuan ambang batas nilai RS dan RPN. Selanjutnya dibuat diagram Acak (scatter diagram) untuk melihat sebaran risiko terhadap nilai RS dan RPN. Ambang batas nilai RS dan RPN digunakan untuk menentukan risiko mana yang termasuk dalam kategori kritis (Tagger, 2011).

Salah satu pengujian yang dilakukan di Laboratorium Uji Kimia $X$ adalah pengujian terhadap cemaran udara ambien yang disebabkan oleh gas SOx (Belerang Oksida). Udara ambien adalah udara yang berada pada lapisan troposfer yang dihirup sehari-hari (BPLH, 2013). SOx merupakan cemaran pada udara ambien yang memiliki karakteristik berbau tajam, bersifat korosif, dan beracun. SOx dapat mencemari sistem pernafasan manusia, pada kadar SOx di udara telah mencapai 3 - 5 ppm maka akan tercium bau khas gas SOx (bau belerang), ketika kadarnya mencapai 8 - 12 ppm maka akan berakibat pada iritasi mata, dan jika kadarnya telah mencapai 500 - 800 ppm di udara maka gas tersebut akan sangat berbahaya bahkan dapat menyebabkan kematian (Saputra, 2009). Pengujian terhadap model pengelolaan risiko SI dilakukan pada proses pengujian kadar SOx (Belerang Oksida) pada udara ambien di Laboratorium Uji Kimia X. Pemetaan sumber-sumber daya SI yang terlibat pada proses pengujian tersebut diperlukan untuk memudahkan tahap identifikasi risiko selanjutnya. Hasil pemetaan sumberdaya SI yang terlibat pada proses bisnis pengujian SOx dapat terlihat pada tabel berikut.

Tabel 2. Pemetaan Sumberdaya SI pada Proses Bisnis Pengujian SOx

\begin{tabular}{lll}
\hline No & \multicolumn{1}{c}{$\begin{array}{c}\text { Kategori } \\
\text { Sumberdaya SI }\end{array}$} & \multicolumn{1}{c}{ Jenis Sumberdaya SI } \\
\hline 1. & Manusia & Analis, Penyelia, Manajer Teknis, Staf IT \\
\hline 2. & Perangkat Lunak & LIMS, Sistem operasi, Sistem Informasi Spektrofotometer \\
\hline 3. & Perangkat Keras & $\begin{array}{l}\text { Peralatan uji standar di laboratorium kimia, Spektrofotometer, alat } \\
\text { Impinger, lemari asam, komputer, printer, dan perangkat keras } \\
\text { teknologi informasi lainnya }\end{array}$ \\
\hline 4. & Data & $\begin{array}{l}\text { Data kadar SOx di udara, data acuan ambang batas SOx, data metode } \\
\text { uji berdasarkan acuan SNI 19-7119.7-2005, data-data penunjang } \\
\text { lainnya }\end{array}$ \\
\hline 5. & Jaringan Komunikasi & Kabel UTP, infrastruktur jaringan \\
\hline
\end{tabular}

Dari hasil identifikasi risiko di Laboratorium Uji Kimia X menggunakan model pengelolaan risiko, diketahui terdapat 16 (enam belas) potensi kegagalan yang berkaitan dengan sistem informasi laboratorium. Risiko-risiko tersebut kemudian diidentifikasi penyebab serta dampak dari kegagalan tersebut. Setelah diketahui penyebab dan dampak kegagalan, dilakukan penilaian dengan menentukan nilai tingkat keparahan dampak (severity / S) dan tingkat kemungkinan kejadian risiko (occurrence / O). Dari nilai S dan O kemudian dihitung nilai Risk Score (RS) melalui rumus RS $=\mathrm{S} * \mathrm{O}$. Selanjutnya dilakukan identifikasi pengendalian yang telah dilakukan saat ini dan dihitung tingkat efektifitas pengendalian untuk mendeteksi 
potensi kejadian risiko (detection / D). Dari hasil perhitungan nilai RS dan RPN, dibuatlah diagram Pareto untuk masing-masing nilai RS dan RPN sebagai bahan evaluasi untuk menentukan ambang batas dari masing-masing nilai. Ditentukan bahwa ambang batas nilai Risk Score (RS) ada di angka 10 dan nilai RPN ada di angka 50, kemudian dibuatlah diagram acak antara nilai RS dan RPN dengan menambahkan garis pada ambang batas masingmasing nilai untuk mendapatkan risiko kritis. Dari hasil diagram acak, diketahui terdapat 2 (dua) risiko yang termasuk kategori kritis dan harus segera ditangani.

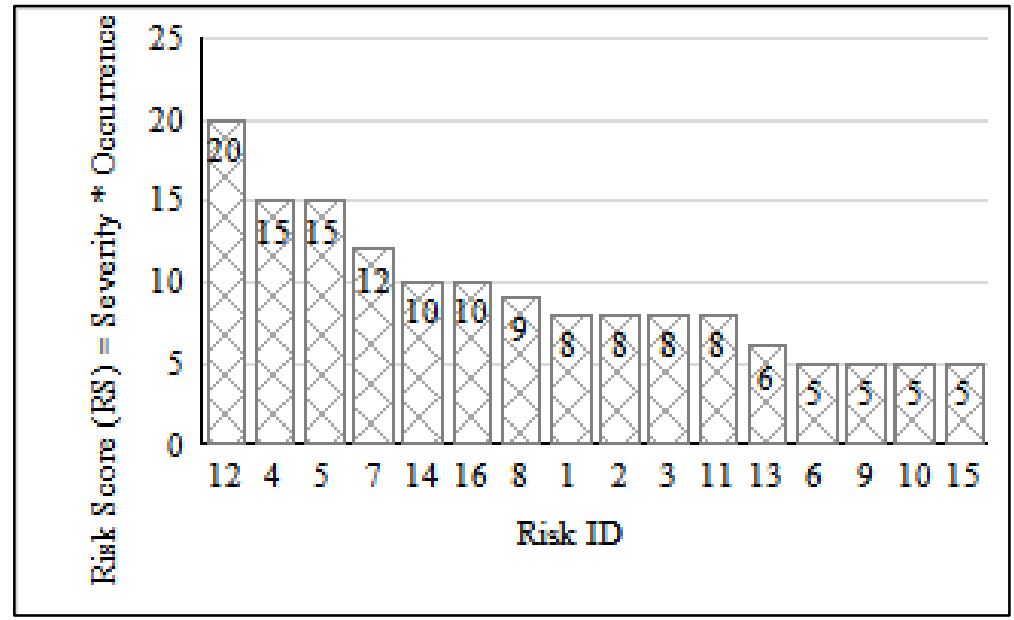

Gambar 2. Diagram Pareto nilai RS

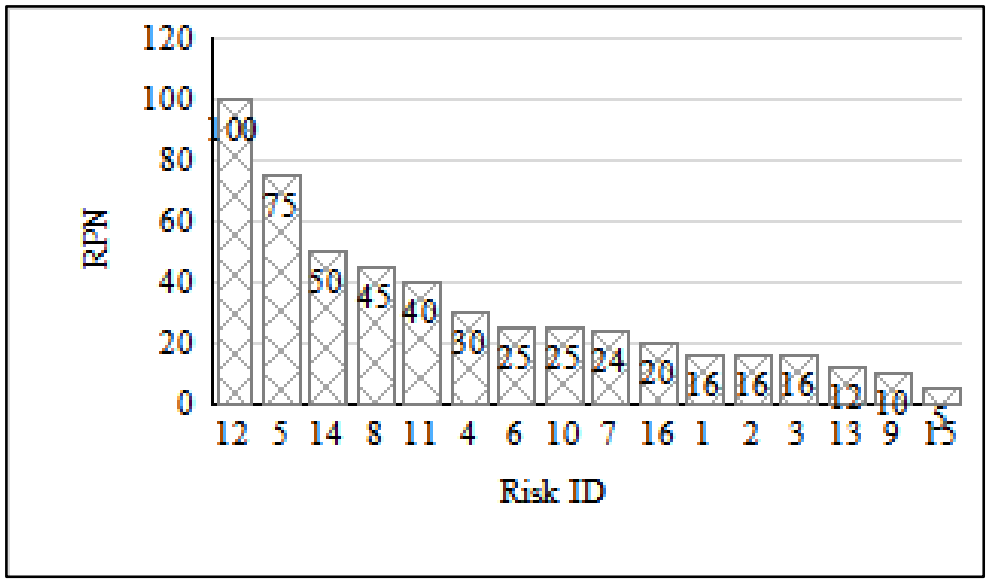

Gambar 3. Diagram Pareto nilai RPN

Model pengelolaan risiko SI berhasil diterapkan pada studi kasus dan menghasilkan 16 (enam belas) risiko yang teridentifikasi pada proses bisnis pengujian kadar SOx di udara ambien, risiko dengan RS terendah yaitu 5 adalah :

1. Kerusakan pada SI Spektrofotometer.

2. Perangkat keras tidak berfungsi akibat gangguan listrik.

3. Kehilangan perangkat keras.

4. Hasil pengujian tidak akurat.

Risiko dengan RS tertinggi yaitu 20 adalah kerusakan kabel UTP, risiko dengan RPN terendah yaitu 5 adalah hasil pengujian tidak akurat, risiko dengan RPN tertinggi yaitu 100 adalah kerusakan kabel UTP, dari diagram acak diketahui terdapat dua risiko yang masuk dalam kategori kritis yaitu kerusakan kabel UTP dan kesalahan input data, kedua risiko kritis 
tersebut di buat usulan tindakan penanganannya menggunakan analisis akar permasalahan. Skala tingkat keparahan dampak risiko (severity), kemungkinan kejadian risiko (occurrence) dan mendeteksi risiko (detection) tersedia pada Tabel 3 yang masing-masing komponen terbagi menjadi 5 tingkat. Sedangkan hasil penilaian risiko sistem informasi pada laboratorium tersedia pada Tabel 4.

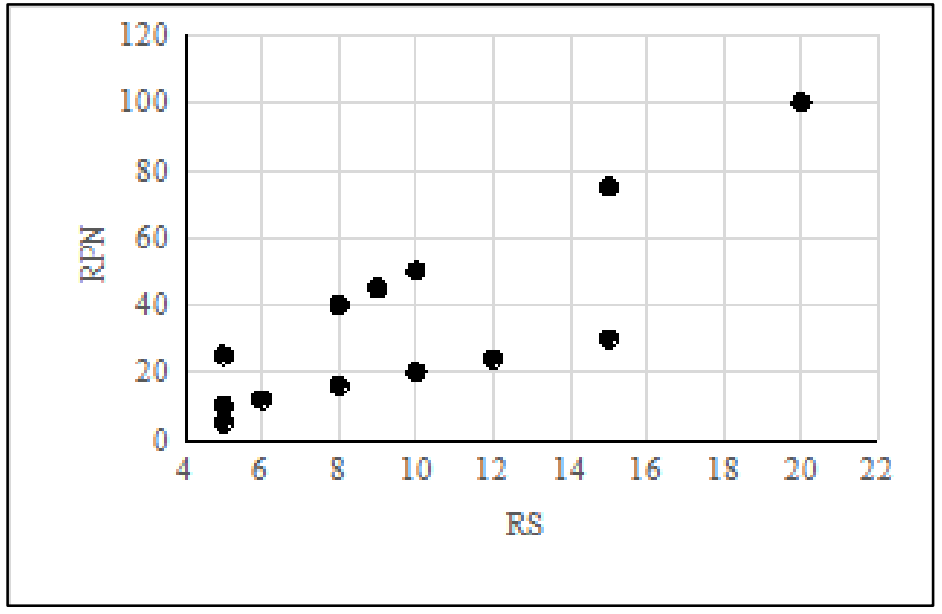

Gambar 4. Diagram acak nilai RPN terhadap RS

Tabel 3. Skala Tingkat Severity, Occurrence dan Detection

\begin{tabular}{|c|c|c|c|c|}
\hline Nilai & Katergori & Severity & Occurrence & Detection \\
\hline 5 & Sangat Tinggi & $\begin{array}{l}\text { Menyebabkan kegagalan } \\
\text { sistem dan atau } \\
\text { menyebabkan kerugian } \\
\text { finansial yang sangat } \\
\text { besar dan kecacatan } \\
\text { permanen pada pekerja }\end{array}$ & $\begin{array}{l}\text { Kemungkinan } \\
\text { terjadi lebih dari } \\
\text { satu kali sehari }\end{array}$ & $\begin{array}{l}\text { Sistem pengawasan } \\
\text { yang dilakukan } \\
\text { tidak mampu } \\
\text { mendeteksi potensi } \\
\text { kejadian risiko }\end{array}$ \\
\hline 4 & Tinggi & $\begin{array}{l}\text { Menyebabkan kegagalan } \\
\text { pada sebagian sistem dan } \\
\text { atau menyebabkan } \\
\text { kerugian finansial yang } \\
\text { besar dan atau luka berat } \\
\text { pada pekerja }\end{array}$ & $\begin{array}{l}\text { Kemungkinan } \\
\text { terjadi setiap } \\
\text { minggu }\end{array}$ & $\begin{array}{l}\text { Sistem pengawasan } \\
\text { yang dilakukan sulit } \\
\text { mendeteksi potensi } \\
\text { kejadian risiko }\end{array}$ \\
\hline 3 & Sedang & $\begin{array}{l}\text { Cukup mengganggu } \\
\text { kinerja sistem dan atau } \\
\text { menyebabkan kerugian } \\
\text { finansial yang tidak terlalu } \\
\text { besar dan atau luka ringan } \\
\text { pada pekerja }\end{array}$ & $\begin{array}{l}\text { Kemungkinan } \\
\text { terjadi setiap } \\
\text { dua minggu }\end{array}$ & $\begin{array}{l}\text { Sistem pengawasan } \\
\text { yang dilakukan } \\
\text { cukup efektif } \\
\text { mendeteksi potensi } \\
\text { kejadian risiko }\end{array}$ \\
\hline 2 & Rendah & $\begin{array}{l}\text { Memiliki kemungkinan } \\
\text { gangguan yang rendah } \\
\text { terhadap finansial maupun } \\
\text { kesehatan pekerja }\end{array}$ & $\begin{array}{l}\text { Kemungkinan } \\
\text { terjadi sekali } \\
\text { dalam satu } \\
\text { bulan }\end{array}$ & $\begin{array}{l}\text { Sistem pengawasan } \\
\text { yang dilakukan } \\
\text { efektif mendeteksi } \\
\text { potensi kejadian } \\
\text { risiko }\end{array}$ \\
\hline 1 & Sangat Rendah & $\begin{array}{l}\text { Tidak menyebabkan } \\
\text { kinerja sistem dan atau } \\
\text { tidak menyebabkan } \\
\text { kerugian finansial dan } \\
\text { gangguan kesehatan }\end{array}$ & $\begin{array}{l}\text { Kemungkinan } \\
\text { terjadi kurang } \\
\text { dari sekali dalam } \\
\text { satu tahun }\end{array}$ & $\begin{array}{l}\text { Sistem pengawasan } \\
\text { yang dilakukan } \\
\text { mampu mendeteksi } \\
\text { potensi kejadian } \\
\text { risiko }\end{array}$ \\
\hline
\end{tabular}


Tabel 4. Hasil Penilaian Risiko Sistem Informasi dengan FMEA

\begin{tabular}{|c|c|c|c|c|c|}
\hline No & Potensi Kegagalan & $\mathbf{S}$ & $\mathbf{0}$ & D & RPN \\
\hline 1. & $\begin{array}{l}\text { Kesalahan dalam membaca data pada alat } \\
\text { spektrofometer }\end{array}$ & 4 & 2 & 2 & 16 \\
\hline 2. & Kesalahan penggunaan alat spektrofotometer & 4 & 2 & 2 & 16 \\
\hline 3. & Kesalahan penggunaan alat Impinger & 4 & 2 & 2 & 16 \\
\hline 4. & Kesalahan pada penanganan contoh uji & 5 & 3 & 2 & 30 \\
\hline 5. & Kesalahan input data & 5 & 3 & 2 & 75 \\
\hline 6. & Kerusakan pada SI spektrofotometer & 5 & 1 & 5 & 25 \\
\hline 7. & Kegagalan Sistem Operasi pada PC & 3 & 4 & 5 & 24 \\
\hline 8. & Kerusakan perangkat keras & 3 & 3 & 2 & 45 \\
\hline 9. & $\begin{array}{l}\text { Kehilangan perangkat keras tidak berfungsi akibat } \\
\text { gangguan listrik }\end{array}$ & 5 & 1 & 5 & 10 \\
\hline 10. & Kehilangan perangkat keras & 5 & 1 & 2 & 5 \\
\hline 11. & $\begin{array}{l}\text { Kegagalan komunikasi akibat kesalahan } \\
\text { konfigurasi }\end{array}$ & 4 & 2 & 1 & 40 \\
\hline 12. & Kerusakan kabel UTP & 4 & 5 & 5 & 100 \\
\hline 13. & Pengungkapan rahasia data & 3 & 2 & 2 & 12 \\
\hline 14. & Double data & 5 & 2 & 5 & 50 \\
\hline & Hasil pengujian tidak akurat & 5 & 1 & 1 & 5 \\
\hline & Kehilangan data & 5 & 2 & 2 & 20 \\
\hline
\end{tabular}

$S=$ severity; $O=$ Occurrence; $D=$ Detecttion; $R P N=$ Risk Priority Number

Selain menggunakan FMEA, metode HIRADC (Hazard Identification, Risk Assessment, and Determinant Control) dapat digunakan sebagai metode alternatif analisis risiko pada laboratorium kimia. Studi yang dilakukan Haqi dkk (2019) menunjukkan bahwa 56 laboratorium kimia di Universitas Airlangga melakukan pemberdayaan kepada setiap pengguna laboratorium agar mampu melakukan analisis risiko bahaya yang ada pada laboratorium kimia di setiap Fakultas dengan metode HIRADC untuk mengurangi risiko bahaya di laboratorium kimia terhadap pekerja dan lingkungan.

Pada proses analisis di laboratorium bahaya yang teridentifikasi adalah : (a) menghirup asam pekat dengan risiko pusing dan mual; (b) kontak dengan asam pekat dengan risiko iritasi kulit; (c) tergores kaca dengan risiko luka gores; (d) menghirup fhenol (untuk analisis kualitas udara ambient) dengan risiko pusing dan mual; (e) terpapar panas COD reaktor dengan risiko luka bakar; (f) terkena bagian dalam oven dengan risiko luka bakar (Permana dkk, 2013). Semua bahan kimia harus terdaftar dalam bentuk yang dikenal sebagai Register of Chemical Hazardous to Health berdasarkan pedoman penyusunan register bahan kimia. Register kimia akan memberikan informasi tentang perdagangan dan nama umum, komposisi kimia, jumlah yang digunakan dan lokasi di mana bahan kimia digunakan atau disimpan. Peraturan Keselamatan dan Kesehatan menetapkan bahwa pemberi kerja harus mengidentifikasi dan mencatat dalam daftar semua bahan kimia yang berbahaya bagi kesehatan yang digunakan di tempat kerja. Register bahan kimia ini digunakan sebagai referensi untuk staf tentang bahaya bahan kimia yang tersedia di tempat kerja mereka dan tindakan pencegahan yang perlu diambil jika terjadi kecelakaan (Husin dkk, 2012).

Selain laboratorium penilaian risiko dengan pendekatan FMEA juga telah diterapkan pada proses pengelolaan limbah medis rumah sakit. (Ho \& Liao, 2011) mengemukakan bahwa risiko tertinggi dalam pada proses pengelolaan limbah medis adalah terjadinya kesalahan pasien dan pengunjung dalam membuang sampah domestik ke wadah limbah infeksius pada ruang perawatan. Sedangkan pada studi (Liao \& Ho, 2014) menunjukkan bahwa praktik wadah limbah tajam infeksius tidak diberi label dengan jelas. Pada studi (Chen \& Tsai, 2017) 
risiko tertinggi pada sistem fungsional produksi di mana laboran mengolah limbah tidak sesuai prosedur. Di Indonesia studi serupa dilakukan oleh Fitria (2020) yang hasilnya RPN tertinggi dihasilkan dari proses penyimpanan, pembuangan dan rencana darurat dengan nilai RPN secara berturut-turut 1425, 1420 dan 1147. Untuk memilih opsi penanganan risiko yang sesuai risiko yang sesuai perlu memperhatikan keseimbangan antara faktor biaya dan faktor besarnya usaha penerapan opsi dilihat dari sudut pandang keuntungan yang akan didapat. Pemilihan opsi juga harus mempertimbangkan faktor hukum, peraturan dan persyaratan lainnya seperti tanggung jawab serta dampak sosial serta dampak terhadap lingkungan hidup.

\section{KESIMPULAN}

Telah berhasil dirancang sebuah model pengelolaan risiko sistem informasi dengan memanfaatkan teknik Failure Mode and Effect Analysis (FMEA) yang didasari oleh proses pengelolaan risiko dari ISO 31000:2009. Dari penilaian ini, dilakukan pemeringkatan tingkat kekritisan risiko melalui Risk Score (RS) dan Risk Priority Number (RPN). Hasil pemeringkatan tersebut nantinya digunakan untuk menentukan prioritas penanganan dan respon risiko. Penilaian yang dilakukan menunjukkan bahwa risiko berbahaya bahan kimia di laboratorium sangat penting dan tindakan pengendalian saat ini dapat lebih ditingkatkan dalam upaya tersebut menyediakan lingkungan kerja yang aman bagi siswa dan staf lab.

Hasil penerapan model pada Laboratorium Uji Kimia X sebagai studi kasus menghasilkan 16 (enam belas) potensi kegagalan. Dari hasil pemeringkatan risiko, diketahui terdapat 2 (dua) risiko yang termasuk kategori kritis. Usulan respon risiko diprioritaskan terhadap risiko-risiko yang termasuk dalam kategori kritis. Usulan dibuat dengan cara menentukan akar permasalahan dari setiap kegagalan dan menentukan pengendalian terhadap setiap akar permasalahan yang teridentifikasi. Selain itu penting untuk mengkomunikasikan risiko kepada seluruh pengguna laboratorium dikarenakan setiap laboratorium akan memiliki kekhasan tersendiri dari risiko bahaya yang dimiliki sehingga diperlukan pembelajaran yang berulang dan sistematis agar permasalahan yang teridentifikasi sesuai dengan risiko bahaya yang ada di laboratorium lingkungan.

\section{DAFTAR RUJUKAN}

Amanah, I. (2011). Identifikasi Bahaya Dan Penilaian Risiko (Risk Assessment) di Laboratorium Studi Kasus di Laboratorium Lingkungan Fakultas Teknik Universitas Diponegoro (Doctoral dissertation, Universitas Diponegoro).

Arnstein, S. R. (1969). A Ladder of Citizen Participation. Dalam R. T. Gates, \& F. Stout (Penyunt.), The City Reader (2nd ed.). New York: Routledge Press.

Borer, M. I. (2010). From Collective Memory to Collective Imagination: Time, Place, and Urban Redevelopment. Symbolic Interaction , 33 (1), 96-144.

Chen, Y.C., Tsai, P.Y. (2017) : Evaluating the operational risks of biomedical waste using failure mode and effects analysis. Waste Management \& Research, 1-9

Fatimah, M., \& Septiawati, D. (2018). Analisis Risiko Kesehatan Lingkungan Akibat Paparan

Benzene Pada Pekerja Laboratorium Pt. Pertamina Ru Iii Palembang Tahun 2018 (Doctoral dissertation, Sriwijaya University). 
Fitria, N. (2020) : Pengembangan penilaian risiko pengelolaan limbah infeksius rumah sakit dengan metode failure mode effect and anaylsis (FMEA) Studi Kasus Rumah Sakit di Daerah Bandung, Disertasi Program Doktor, Institut Teknologi Bandung.

Haqi, D. N., Dwiyanti, E., Mulyono, M., \& Alayyannur, P. A. (2019). Pemberdayaan Petugas Laboratorium Untuk Terciptanya Laboratorium Safety Di Lingkungan Universitas Airlangga. Jurnal Layanan Masyarakat (Journal of Public Services), 3(2), 58-60.

Ho, C.C., Liao, C.J. (2011) : The use of failure mode and effect analysis to construct an effective disposal and prevention mechanism for infectious hospital waste. Waste Management, 31, 2631-2637Kartikasari, D., Nurjazuli, N., \& Rahadjo, M. (2016). Analisis Risiko Kesehatan Pajanan Benzene pada Pekerja di Bagian Laboratorium Industri Pengolahan Minyak Bumi. Jurnal Kesehatan Masyarakat (Undip), 4(4), 892-899.

Husin, S. N. H., Mohamad, A. B., Abdullah, S. R. S., \& Anuar, N. (2012). Chemical health risk assessment at the chemical and biochemical engineering laboratory. Procedia-Social and Behavioral Sciences, 60, 300-307.

Liao, C.J., Ho, C.C. (2014) : Risk management for outsourching biomedical waste disposal Using the Failure Mode Effect Analysis, Waste Management Journal, 34 , 1324-1329 Mac Leod, D. (1992). Post-Modernism and Urban Planning. Dipetik June 25, 2010, dari http://www3.sympatico.ca/david.macleod/POMO.HTM

Permana, A. A., Nugraha, W. D., \& Hadiwidodo, M. (2013). Analisis Manajemen Risiko Studi Kasus: Unit Pelaksana Teknis Balai Pengujian dan Laboratorium Lingkungan Hidup Badan Lingkungan Hidup Provinsi Jawa Tengah. Jurnal Teknik Lingkungan, 2(2), 1-11.

Poston, J. D., \& Bouvier, L. F. (2010). An Introduction to Demography. Cambridge: Cambridge University Press.

Stoica, R.-I. (2006 [2005]). Heterotopia Urbana: Some Conceptual Considerations of Urban Heritage. Forum UNESCO University and Heritage 10th International Seminar "Cultural Landscapes in the 21st Century". Newcastle-upon-Tyne.

Voskuil, R. P. (1996). Bandoeng: Beeld van Een Stad (Indonesian ed.). (S. M. Supardan, S. Sumardi, N. Darsono, \& I. I. Yousda, Penerj.) Bandung: Dept. Planologi and Jagaddhita.

Xi, Z. (2004). Comparison between American and Chinese Community Building. Dipetik May 10, 2007, dari COMM-ORG: The On-Line Conference on Community Organizing and Development: http://comm-org.wisc.edu/papers2004/zhangxi.htm

BPLH (Badan Pengelolaan Lingkungan Hidup) (2013) : Hasil Pemantauan Udara Ambien Roadside Kota Bekasi, Situs Web BPLH Kota Bekasi, 
http://bplh.bekasikota.go.id/read/118/hasil-pemantauan-udara-ambien-roadside-kotabekasi, diakses 5 Juni 2014.

Carbone, T.A, dan Tippett, D.D. (2004) : Project Risk Management Using the Project Risk FMEA, Management Engineering Journal, 16, 28-35.

Helfrich, J.P. (2008) : Thin LIMS, Thick LIMS - New IT Implementation Strategy for cGMP Qualyti Informatics, Velquest White Paper.

ISO (International Organization for Standardization) (2009) : International Standard : Risk Management - Principles and Guidelines , ISO Copyright Office, Geneva, Switzerland.

Jakaria, D.A., Dirgahayu, R.T., Hendrik. (2013) : Manajemen Risiko Sistem Informasi Akademik Perguruan Tinggi menggunakan Metode Octave Allegro, Seminar Nasional Aplikasi Teknologi Informasi (SNATI), E-37 - E-42.

Jones, J.A. (2005) : An Introduction to Factor Analysis of Information Risk (FAIR), Risk Management Insight (RMI), http://www.riskmanagementinsight.com/media/docs/FAIR_introduction.pdf, diakses 10 Februari 2014

Laudon, K.C., dan Laudon, J.P. (1998) : Management Information Systems : New Approach to Organization and Technology, 5th edition, Prentice Hall, New Jersey, USA.

Liscouski, J. (1995) : Laboratory and Scientific Computing : a Strategic Approach, John Wiley and Sons, Inc., New York, USA.

Madigan, N. (2012) : Laboratory Informatics : Current Trends and Predictions for 2015, Pharma-IQ Survey Report, 11th Annual ELNs and Advanced Laboratory Solutions.

McLeod Jr, R. dan Schell G.P. (2008) : Management Information System, 10th edition, Terjemahan Yulianto, A.A. dan Fitriati, A.R., Penerbit Salemba Empat, Jakarta, http://books.google.co.id/books?id=2aXEg7DtCS0C\&printsec=frontcover\&hl=id\&source=g bs_ge_summary_r\&cad=0\#v=onepage\&q\&f=false, diakses 20 Februari 2014.

Novak-deLaurell, C. (2014) : Mitigating the Common Pitfalls of LIMS Implementation, European Pharmaceutical Review, 19, 22-24.

O'Brien, J.A., dan Marakas, G.M. (2011) : Management Information System 10th edition, McGraw-Hill/Irwin, New York, USA, https://app.box.com/s/55qmp5a9i7vcwhb3t8yv, diakses 27 Februari 2014.

Peffers, K., Tuunanen, T., Rothenberger, M.A, dan Chaterjee, S. (2008) : A Design Science Research Methodology for Information Systems Research, Journal of Management Information Systems, 24(3), 45-77. 
Paszko, C. dan Pugsley, C. (2000) : Considerations in Selecting a Laboratory Information Management System (LIMS), American Laboratory, 32, 38-42.

PMI (Project Management Institute) (2002) : A Guide to Project Management Body of Knowledge (PMBOK Guide), Project Management Institute Inc, Newton Square, Pennsylvania, USA.

Saputra, Y.E. (2009) : Dampak Pencemaran Udara oleh Belerang Oksida (SOx), Situs Kimia Indonesia (chem-is-try.org), http://www.chem-istry.org/artikel_kimia/kimia_lingkungan/dampak-pencemaran-udara-oleh-belerang-oksidasox/, diakses 5 Juni 2014

Slay, J. dan Koronios, A. (2006) : Security and Risk Management, John Wiley and Sons, Inc.

Subamia, I. D. P., Sriwahyuni, I. G. A. N., \& Widiasih, N. N. (2019). Analisis Resiko Bahan Kimia Berbahaya di Laboratorium Kimia Organik. Wahana Matematika dan Sains: Jurnal Matematika, Sains, dan Pembelajarannya, 13(1), 49-70.

Tagger, B. (2011) : An Introduction and Guide to Successfully Implementing a LIMS (Laboratory Information Management System), Computer Science Departement, University of Wales, Aberystwyth, Ceredigion, Wales, http://www.cs.ucl.as.uk/staff/B.Tagger/LimsPaper.pdf, diakses 7 Februari 2014.

Wiesche, M., Schermann, M., Kesinov, H., dan Krcmar, H. (2013) : Clasifying System Risks : What We Have Learned So Far, Hawaian International Conference on System Sciences, 46, 5013-5022.

Yaumi, N.T, dan Surendro, K. (2012) : Model Pengelolaan risiko pada Penerapan Cloud Computing untuk Sistem Informasi di Perguruan Tinggi Menggunakan Framework COSO ERM dan FMEA (studi kasus: ITB) : Jurnal Sarjana Institut Teknologi Bandung Bidang Teknik Elektro dan Informatika, 1.

Yu, M. (2012) : Risks Assosiated with Laboratory Informatics : Avoiding the Pitfall that Can Harm Patients, Clinical Laboratory News, 35, 14.

Yucel, G., Cebi, S., Hoege, B., dan Ozok, A.F. (2011) : A Fuzzy Risk Assessment Model for Hospital Information System Implementation, Expert Systems with Applications, 39, 12111218.

Zhu, J. (2005) : Automating Laboratory Operations by Integrating Laboratory Information Management Systems (LIMS) with Analytical Instruments and Scientific Data Management Systems (SDMS), Master Thesis, Laboratory Informatics Graduate Program, Schools of Informatics, Indiana University, p.2-4. 